UDC: 502.172631 .147

COBISS.SR-ID: 228212492

Review paper

Acta Agriculturae Serbica, Vol. XXI, 42 (2016) 123-134

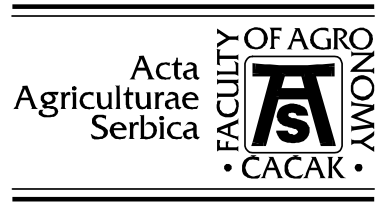

\title{
Biodiversity and organic agriculture
}

\author{
Milovan Veličković ${ }^{1}$, Jelena Golijan ${ }^{1}$ and Aleksandar Popović ${ }^{2}$ \\ ${ }^{I}$ Faculty of Agriculture, University of Belgrade-Zemun, Belgrade, Serbia \\ ${ }^{2}$ Maize Research Institute, "Zemun Polje“, Belgrade, Serbia \\ *Corresponding author: e-mail: mvelicko@agrif.bg.ac.rs
}

\begin{abstract}
Biodiversity on the planet Earth has been threatened for decades, primarily due to human activities. According to current scientific knowledge, the number of species decreases at a rate of 1,000 to 10,000 times higher than in previous times. Even though international strategic goals aim stopping the global changes in the existing biodiversity, it can be concluded that as many as 74 species daily disappear, that is 27,000 species annually, implying the disappearance of $20 \%$ of recent species in the next three to four decades. Preserving biodiversity is one of the most important goals of global environmental protection, sought for science and policy to participate in. Adopted Conventions on biological diversity and biodiversity, provide a key indication of progress towards achieving the Strategic Plan for Biodiversity (20112020). Biological diversity necessitates a comprehensive help of modern man, at all levels of operation, in order to preserve and certainly enrich the existing biodiversity. To protect the numerous and very rare species numerous legal regulations, primarily the law on nature protection, must be introduced and strictly observed. The organic production system preserves not only local but also global biodiversity. According to all recent scientific research, this system of agricultural production increases not only the number of different types of organisms, but also their overall growth, with slight variations among different taxonomic groups.
\end{abstract}

Key words: biodiversity, threatened species, environment, Conventions on Biological Diversity, organic production 


\section{Introduction}

The existence of life is a single unique characteristic of Earth, and the diversity of life is an exceptional characteristic. Earth is inhabited by approximately nine million species of plants, animals, fungi and protests (Cardinale et al., 2012). The land cover is the most important direct driver of global biodiversity loss in the past 60 years, and it is predicted to have an increasing impact in most ecosystems (Gagné et al., 2015). The majority of specialists and experts in biodiversity state that effects of climate changes on survival and diversity of species, i.e. diversity of the complete living world, are very harmful; hence, biodiversity will not be excluded because it is an evolutionary response to climate changes. The National Strategy for Biodiversity of the Republic of Serbia defines biodiversity as one of primary natural resources, inseparably associated with the ecological system not only of Serbia, but also of the entire world.

Reducing the rate of biodiversity loss, as well as, the prevention of dangerous biodiversity changes are international goals reasserted by the Aichi Targets for 2020 by Parties to the United Nation Convention on Biological Diversity after the failure to meet the 2010 targets. However, the additional issues are related to non-existence of globally harmonised system for delivering regular, timely data on biodiversity changes.

With the first plenary meeting of the Intergovernmental Science-Policy Platform on Biodiversity and Ecosystem Services (IPBES) soon under way, partners from the Group on Earth Observations Biodiversity Observation Network will reach consensus related to the Essential Biodiversity Variables that could form the basis of monitoring programmes worldwide (Pereira et al., 2013). The Convention on Biological Diversity (CBD) and five other biodiversityrelated conventions have adopted IPBES as their science-policy interface, so these assessments will be important in evaluating progress towards CBD's Aichi Targets of the Strategic Plan for Biodiversity 2011-2020 (Pimm et al., 2014).

The aim of this paper is to analyse the available literature data in order to point out to the increasing importance of the concept of organic agriculture, because it is a system that provides the increase in the number of species, and also in groups of organisms in relation to conventioal agriculture with the special emphasis on the respcet for diverisity of species and the presence of plants, insects, soil micro- and macro-fauna. This type of production with the application of the highest standards of animal and plant health protection preservers and imporves soil biodiversity, controls and increases its fertility and protects the environment (Filipović \& Ugrenović, 2012). 


\section{Biodiversity}

Survival of humans on the planet Earth is certainly conditioned by the preservation of its natural resources, which is based on the total biodiversity of the living world (Momirović \& Veličković, 2000; Đukić \& Mandić, 1997). Due to this fact, the concept of protection and conservation of biodiversity is a part of all previous development strategies. According to the Millennium Ecosystem Assessment, the image of nature and its biodiversity has drastically changed in the past 50 years (UNEP, 2006; Sala et al., 2000; Schnieders et al., 2012). Hawksworth (2001) reported that man is one of main factors affecting changes in biodiversity, not just locally but globally too. One of approaches to the planning of economic and general social develeopment with the particular emphasis on a balanced use of resoureces and conservation of the environment and the entire nature, was adopted by the Convention of Biological Divresity at the conference held in Rio de Janeiro in 1992 (Institute for Nature Conservation of Serbia, 2016).

Biological diversity requires the help of modern man at all levels of organisations from geographic to socio-political (diversity incited better cooperation among 191 countries) (Veličković, 1997, Redžić, 2012). There are many definitions and even more measures of biodiversity, but one of the most accepted and used definition is Bruce Wilcox's definition, that "diversity is the variety of life forms, their ecological role and genetic diversity" (Berberović, 2012). The 1992 Convention on Biodiversity defined this term as "the variability among living organisms from all sources, including 'inter alia', terrestrial, marine, and other aquatic ecosystems, and the ecological complexes of which they are part: this includes diversity within species, between species and of ecosystems" (Oljača, 2012). For many researchers, species are the basic unit of biodiversity, while species richness is a measure that can be expressed in various ways, which reflect relative abundance, or ecological or evolutionary relationships among species (Mace et al., 2013). The World Summit on Sustainable Development took place in Johannesburg in 2002, while the United Nations declared the year of 2010 as the International Year of Biodiversity, and on that occasion was reported that biodiversity was life. After the Year of Biodiversity, celebrations held all over the world with the aim to propagate and spread its value across the entire planet. The Resolution 61/203 on the International Year of Biodiversity in 2010 was adopted by the UN General Assembly at its $61^{\text {st }}$ session in 2006, when key targets on the implementation of the Convention of Biological Diversity (CBD, 2010) were set. The aim of the International Year of Biological Diversity was in fact a need to seek for help and to raise awareness throughout the public on its importance through the implementation of a series of activities in a number of countries, which would 
affect the decision making and "raise biological diversity closer to the top of political agenda" (Redžić, 2012).

Biodiversity encompasses three levels of organisation: 1) genetic code that implies diversity of genetic material of individuals and populations within the same species, 2) species level that encompasses organic species on Earth since the beginning of life until the present day, and finally 3) ecosystem level that includes diversity of habitats, biocenoses, ecosystems and ecological processes (LeCointre \& Guyader, 2001). According to Cracraft (2002), approximately 1.5 to 1.75 million species have been classified and described (there are around one million of animal species and approximately a half a million plant species). Kovačević et al. (2011) have reported that more than 600 animal species and around 900 plant species had disappeared from Earth in the past 500 years. Based on the Red List of Threatened Species of the International Union for the Conservation of Nature and Natural Resources (IUCN), $9 \%$ of European species of mammals are considered near threatened, while $15 \%$ is already threatened. Furthermore, $27 \%$ of species are declining in population (Institute for Nature Conservation of Serbia, 2016). Globally, approximately $21 \%$ of mammals are threatened. However, mammals are not the most endangered species, but amphibians are with $30 \%$ globally and $25 \%$ at the European level, while more than $50 \%$ stagnate. Considering the group of reptiles, the fact that only $30 \%$ of species have been globally assessed is a great problem. Approximately $21 \%$ of these species are threatened of which one fifth is in Europe. In addition, even more striking fact is the information that these threatened species are endemic species.

Scenarios of changes in biodiversity for the year 2100 can now be developed based on scenarios of changes in atmospheric carbon dioxide, climate, vegetation, land use and the known sensitivity of biodiversity to these changes. For terrestrial ecosystems, land-use change probably will have the largest effect, followed by climate change, nitrogen deposition, biotic exchange, and elevated carbon dioxide concentration (Sala et al., 2000) In order to protect numerous very rare species, and then those threatened, many legal regulations have been adopted. The Republic of Serbia is one of many countries in the world that signed the current international conventions on biodiversity (Convention Ramsar, Convention CITES, Convention Bern, Convention Bonn). Furthermore, with the aim to preserve biodiversity of the Republic of Serbia at both international and national level, the Biodiversity Strategy of the Republic of Serbia for the period 2011-2018 was adopted (Institute for Nature Conservation of Serbia, 2016). 


\section{Biodiversity of the Republic of Serbia}

Serbia represents a country with a rich and highly diverse ecosystem types, while occupying only $1.9 \%$ of the territory, making her one of the six centers. Said diverse ecosystems of the Republic of Serbia is reflected in the different and specific territorial part, Featuring as a country with a wide variety of genetic, species and ecosystem diversity. According to available data, in the territory of the Republic of Serbia has officially registered near 44200 taxa (Institute for Nature Conservation of Serbia, 2016). On its territory is located 62 Important Plant Areas (IPA), 42 Important Bird Areas (IBA) and 40 Prime Butterfly Area (PBA) (cmsdata.iucn.org ). Due to the great biological diversity of different groups of organisms, it is this kind make up a significant part of European biodiversity. According to the International Union for Conservation of Nature in Serbia is $39 \%$ of the vascular flora, $51 \%$ of European fish species, $40 \%$ of European amphibians and reptiles, $74 \%$ of birds and $67 \%$ of European mammals (IUCN, 2016). Also, the same sources say that in Serbia are vulnerable and at risk of disappearance of the following types: $70 \%$ of all known species of plants, $37 \%$ of fish, invertebrates, $35 \%, 30 \%$ of amphibians, $28 \%$ of reptiles and $21 \%$ of species mammals. In order to protect a number of very rare species, then those who are vulnerable, there are numerous legal regulation: the Nature Protection Act, the Ordinance on the criteria for the separation of habitat types, the types of habitat, vulnerable, endangered, rare and for the protection of priority habitat types and on measures for their conservation, the Ordinance on proclamation and protection of strictly protected and protected wild species of plants, animals and fungi, the Ordinance on transboundary movement and trade in protected species and the Decree on control of use and trade of wild flora and fauna (Institute for nature Conservation of Serbia, 2016).

\section{Preservation of biodiversity by organic agriculture}

In the present day, the extinction of species is one of the main problems of biodiversity, even though it is a part of natural evolutionary processes. Reports released by the Millennium Ecosystem Assessment (2005) pointed out that 74 species extinct daily, i.e. 27,000 species annually, meaning that in the next 30 years $20 \%$ of recent species will be irreversibly lost. Oljača (2012) stated the reasons for the biodiversity decline: 1) disturbance of habitats (human activity is fundamentally changing natural habitats of species, due to which they are becoming extinct), 2) invasive/introduced species (become a problem because they do not belong to the complex of biotic relationships with organisms within whose biocenosis they have been introduced, due to which they have no natural enemies that would keep their number at a stable level, hence they create problems to autochthonous species; Colorado potato beetle is one of such 
species in Europe), 3) pollution (introduction of energy and harmful substances into the environment that will remain in their original non-degraded state due to impossibility of their degradation in biochemical cycles, 4) excessive growth of the human population that results in 5) excessive exploitation of natural resources (although biological resources are renewable, the human activity leads to their exploitation that is greater than the reproductive potential of the species).

The process of the diversity decline has been present for decades even in agro-ecosystems. Genotypes have been lost, and many of existing genotypes have been endangered with the threat of extinction. All this has been followed by the occurrence of uniformity of the genetic basis of the increasing number of major crops. Conventional agriculture with its production systems have resulted in the simplification of the agro-ecosystem structure, with a consequence that biodiversity in them was reduced to a lower number of crops and domestic animals. Globally, in all climate zones, 35 fruit species, 23 vegetable species and 12 cereal species have been grown, which represents only 70 species on the area of about 1,440 million hectares. This is very poor in comparison with the biodiversity of tropical rain forests, where more than 100 species of woody plants only may be found on the area of one hectare (Oljača, 2012). During the next 50 years, the global expansion of the agricultural production threatens biodiversity with the consequences of the unprecedented scale that can compete with the relevance of climate changes (Tilman et al., 2001).

The objectives of organic production are the increase and maintenance of soil fertility, protection of natural resources from pollution, erosion prevention, conservation of biodiversity and omission, to the greatest possible extent, of inputs originating outside of the farm (Filipović \& Ugrenović, 2012). Organic agriculture provides not only food safety, but also conservation of biodiversity and the entire environment (Popović et al., 2016). Weibull et al. (2003) performed studies on flora of conventional and organic crops and determined twice as many weed species in organic crops, especially species of the families Fabaceae, Brassicaceae and Polygonaceae. A much greater diversity of plant species was generally detected in the organic production system than in the conventional one.

Considering soil biodiversity, especially microbial communities of bacteria and fungi, data obtained between organic and conventional regimes are limited. However, there is evidence that there is a general trend of growth of nematodes, bacteria and fungi in organic systems (the increase of microbial biomass by 10 $26 \%$ ). The addition of manure and green manure are the main growth factors (Shannon et al., 2002).

Feber et al. (1997) recorded a significantly higher presence and growth of butterflies on organic farms. The same authors detected not only more active spider communities in organic wheat crops, but greater abundance of species than in conventional crops. Hutton \& Giller (2003) stated that organic farms had 
significantly greater beetle biomass, diversity and species richness by $38 \%$ on average compared to conventional farms. Brown (1999) found out that the activity of small mammals, particularly Apodemus sylvaticus, Clethrionomys glareolus, Lepus europaeus and Sorex araneus, was greater in farms with organic production. Wickramasinghe et al. (2003) reported that the total bat activity of all species was significantly higher (on the average by 61-84\%), which points out to the fact that these species prefer organic over conventional habitats, due to greater abundance of various insect species important to bats as food.

Table 1. Summary of the effects of organic farming on individual taxon, in comparison to conventional farming

\begin{tabular}{lccc}
\hline Taxon & Positive & Negative & $\begin{array}{c}\text { Mixed/No } \\
\text { differences }\end{array}$ \\
\hline Birds & 7 & & 2 \\
Mammals & 2 & & \\
Butterflies & 1 & & 1 \\
Arachnids & 7 & 2 & 3 \\
Worms & 7 & 5 & 3 \\
Beetles & 13 & 1 & 2 \\
Other invertebrates & 7 & & 2 \\
Plants & 13 & & 8 \\
Soil microbes & 9 & 8 & 25 \\
\hline Total & 66 & & \\
\hline
\end{tabular}

Source: Hole et al. (2005)

All previous studies show that bird abundance on organic farms were 2-2.6 times higher, on average, than on non-organic farms (Beecher et al., 2002), and that density and the number of their nests, especially of species Alauda arvensis, Turdus merula and Carduelis chloris, were greater in the European countries.

Organic production increases the richness of species and according to previous data this increase amounts to $30-50 \%$ in comparison with conventional agricultural systems (Table 1), with the emphasis that variations among certain groups were detected (a positive response are determined in species such as birds, predatory insects, soil organisms and plants). Similar results were obtained by Bengtsson et al. (2005) in their study on effects of organic and conventional agriculture on biodiversity (Table 2): organic farming usually increases species richness, having on average $30 \%$ higher species richness than conventional farming systems; birds, insects and plants usually showed an increased species richness in organic farming systems; on average, organisms were 50\% more abundant in organic farming systems, but the results were highly variable 
between studies and organism groups; birds, predatory insects, soil organisms and plants responded positively to organic farming, while non-predatory insects and pests did not. The positive effects of organic farming on abundance were prominent at the plot and field scales, but not for farms in matched landscapes. Water ecosystems and biodiversity within them have great benefits of organic agriculture, because pollution of streams with pesticides and various inorganic fertilisers is reduced (due to which the number of aquatic species is decreased), thus nitrate leaching is reduced and thereby the quality of water is improved.

Table 2. A meta-analysis of the effects of organic agricultural methods on species richness.

\begin{tabular}{|c|c|c|c|c|c|}
\hline & $\begin{array}{c}\text { Average effect size } \\
\text { (Hedges'g) }( \pm 95 \% \\
\text { CL) }\end{array}$ & $n$ & $Q$ & $\begin{array}{l}\text { No. of positive } \\
\text { studies }\end{array}$ & $n$ \\
\hline Total & $1 \cdot 152( \pm 0 \cdot 524)_{-}^{*}$ & 32 & $170^{*}$ & $53 *$ & 63 \\
\hline \multicolumn{6}{|c|}{ By organism group } \\
\hline Birds & $1 \cdot 495( \pm 1 \cdot 236)_{-}^{*}$ & 2 & 0 & 3 & 3 \\
\hline Arthropods & $0.929( \pm 0 \cdot 589)_{-}^{*}$ & 19 & $71 \cdot 7 *$ & $21 *$ & 28 \\
\hline $\begin{array}{l}\text { Predatory } \\
\text { insects }\end{array}$ & $0.843( \pm 0 \cdot 590)_{-}^{*}$ & 15 & $43 \cdot 8 *$ & 15 & 21 \\
\hline Carabidae & $0 \cdot 941( \pm 0 \cdot 861)_{-}^{*}$ & 11 & $34 \cdot 7 *$ & 10 & 13 \\
\hline $\begin{array}{l}\text { Non- } \\
\text { predatory } \\
\text { arthropods }\end{array}$ & $1 \cdot 046( \pm 1 \cdot 982)$ & 4 & $26 \cdot 2 *$ & 6 & 7 \\
\hline $\begin{array}{l}\text { Soil } \\
\text { organisms }\end{array}$ & $0 \cdot 306( \pm 0 \cdot 559)$ & 5 & $3 \cdot 3$ & 7 & 10 \\
\hline Plants & $2 \cdot 684( \pm 1 \cdot 976)^{*}$ & 6 & $81 \cdot 6 *$ & $22 *$ & 22 \\
\hline \multicolumn{6}{|c|}{ By scale of study } \\
\hline $\begin{array}{l}\text { Plot or single } \\
\text { field }\end{array}$ & $2 \cdot 917( \pm 1 \cdot 769)_{-}^{*}$ & 8 & $55 \cdot 8 *$ & $15_{-}^{*}$ & 17 \\
\hline $\begin{array}{l}\text { Field on farm } \\
\text { Field/farm in }\end{array}$ & $0 \cdot 703( \pm 0 \cdot 550)_{-}^{*}$ & 11 & $19 \cdot 3 *$ & $24_{-}^{*}$ & 27 \\
\hline $\begin{array}{l}\text { matched } \\
\text { landscape }\end{array}$ & $0 \cdot 818( \pm 0 \cdot 791)_{-}^{*}$ & 13 & $79 \cdot 6_{-}^{*}$ & 14 & 19 \\
\hline \multicolumn{6}{|c|}{$\begin{array}{l}\text { Positive effect sizes indicate higher species richness in organic farming systems. The number of positive } \\
\text { studies column and the associated } \mathrm{n} \text { column include all studies, and those in which no quantitative effect size, } \\
\text { only increases or decreases in species richness, was given. When } \mathrm{Q} \text { (heterogeneity of effect sizes among } \\
\text { studies) is significant, the results are shown for a random effects model. *P }<0 \cdot 05 \text { for average effect size } \neq 0 \text {, } \\
\text { for heterogeneity of effect sizes (Q) and for binomial test of the number of positive studies; CL, confidence } \\
\text { limit. Source: Bengtsson et al., 2005 }\end{array}$} \\
\hline
\end{tabular}

Table 3 presents effects of organic production on biodiversity, environment and other resources based on mean data from 18 countries in which this system is actively applied (Stolze et al., 2000). 
Table 3. Rating of the importance of environmental and resource use effects of organic farming according to country specific expert opinion. Mean data from 18 countries.

\begin{tabular}{lcc}
\hline Indicator & Rating & Mean \\
\hline Biodiversity & $1-5$ & 3.3 \\
Landscape & $1-4$ & 2.8 \\
Climate and air & $1-5$ & 2.7 \\
Soil & $2-5$ & 4.2 \\
Ground and surface water & $2-5$ & 4.0 \\
Energy use & $1-4$ & 2.8 \\
\hline
\end{tabular}

*Legend: 5=very important, 4=important, 3=average, 2=not so important, 1=unimportant; Source: Stolze et al., 2000.

Although assessments of experts on effects of this production on the environment vary from country to country, mean values indicate that there is the highest positive effect on soil (and biodiversity within it), ground and surface water and complete biodiversity.

\section{Conclusion}

A great number of pollutants worldwide affected climate changes, ozone layer damages, disturbance of biodiversity and generally of biological equilibrium, then resulted in the irreversible loss of numerous species of flora and fauna. Due to the loss of global biodiversity that has been happening for the last 60 years, there are numerous national strategies for biodiversity, which designated biodiversity as a part of basic resources of the planet Earth that is inseparably linked to and important for every ecosystem. Reducing the rate of disappearance of species and prevention of drastic changes in biodiversity are international strategic objectives until 2020.

In the last ten years, due to increased public concern regarding food safety and threatened natural resources, organic agriculture has been gaining importance. An ecological system of food production, i.e. organic agriculture, is one of safe methods to establish the preservation of the natural ecosystem. Despite numerous difficulties in the identification of many causes related to "declaring" differences in biodiversity between conventional and organic agriculture, the majority of studies show the same evidence and conclusion that organic production provides not only preservation of biodiversity with the production of organic food without pesticide remains, but preservation of the entire ecosystem. 


\section{References}

Assessment, M. E. (2005): Ecosystems and Human Wellbeing: Synthesis. Island Press, Washington, DC.

Berberović, L. (2012): Biodiverzitet-pojam i fenomenologija. Drugi međunarodni kolokvijum „Biodiverzitet-Teorijski i praktični aspekti”. Zbornik radova, Sarajevo, Bosna i Hercegovina, 22: 37-46.

Beecher, N. A., Johnson, R. J., Brandle, J. R., Case, R. M., Young, L. J. (2002): Agroecology of birds in organic and nonorganic farmland. Conservation biology, 16(6): 1620-1631.

Bengtsson, J., Ahnström, J., Weibull, A. C. (2005): The effects of organic agriculture on biodiversity and abundance: a meta-analysis. Journal of applied ecology, 42(2): 261269.

Brown, R.W.(1999): Margin/field interfaces and small mammals. Aspects of Applied Biology, 54: 203-210.

Cardinale, B. J., Duffy, J. E., Gonzalez, A., Hooper, D. U., Perrings, C., Venail, P.,Narwani, A., Mace, G.M., Tilman, D., Wardle, D.A, Kinzig, A.P, Daily, M.L, Kinzig, A. P., Daily, G.C, Loreau, M., Grace, J.B, Larigauderie, A., Srivastava, D.S, Naeem, S. (2012): Biodiversity loss and its impact on humanity. Nature, 486(7401): 59-67.

CBD. 2010: Secretariat of the Convention on Biological Diversity (2010), Global Biodiversity Outlook 3, May, 2010: 56.

Cracraft, C. (2002): The seven great questions of systematic biology: an essential foundation for conservation and the sustainable use of biodiversity. Annals of the Missouri Botanical Garden, 89: 127-144.

Đukić, D., Mandić, L. (1997): Poljoprivredna biotehnologija i zaštita životne sredine. Ecologica, 16 (4): 13-18.

Feber RE, Firbank LG, Johnson PJ. \& Macdonald DW. 1997: The effects of organic farming on pest and non-pest butterfly abundance. - Agriculture, Ecosystems and Environment 64: 133-139

Filipović, V. \& Ugrenović, V. (2012): Biodiverzitet zemljišta u sistemima organske proizvodnje. II Otvoreni dani biodiverziteta. Zbornik referata, Pančevo, 26. jun 2012. godine.

Gagné, S. A., Eigenbrod, F., Bert, D. G., Cunnington, G. M., Olson, L. T., Smith, A. C., Fahrig, L. (2015): A simple landscape design framework for biodiversity conservation. Landscape and Urban Planning, 136: 13-27.

Hawksworth, D. L. 2001: The magnitude of fungal diversity: the 1.5 million species estimate revisited. Mycological Research, 105(12): 1422-1432.

Hole, D. G., Perkins, A. J., Wilson, J. D., Alexander, I. H., Grice, P. V., Evans, A. D. (2005): Does organic farming benefit biodiversity? Biological conservation, 122(1): $113-130$.

Hutton, S. A. \& Giller, P. S. (2003): The effects of the intensification of agriculture on northern temperate dung beetle communities. Journal of Applied Ecology, 40(6): 994-1007.

Lecointre, G. \& H. Le Guyader (2001): Classification phylogenetique du vivant. Paris, France: Belin. 
Mace, G. M., Norris, K., Fitter, A. H. (2012): Biodiversity and ecosystem services: a multilayered relationship. Trends in ecology \& evolution, 27(1), 19-26.

Momirović, N., Veličković, M. (2000): Koncept održivog razvoja poljoprivrede u funkciji zaštite životne sredine. Ecologica, 25 (2): 127-135.

Oljača, S. (2012): Poljoprivreda i biodiverzitet. Organska proizvodnja i biodiverzitet, 325.

Pereira, H. M., Ferrier, S., Walters, M., Geller, G. N., Jongman, R. H. G., Scholes, R. J., Coops, N. C. (2013): Essential biodiversity variables. Science, 339 (6117): 277-278.

Pimm, S. L., Jenkins, C. N., Abell, R., Brooks, T. M., Gittleman, J. L., Joppa, L. N., Raven, P.H, Roberts, C.M, Sexton, J. O. (2014): The biodiversity of species and their rates of extinction, distribution, and protection. Science, 344 (6187):1246752.

Popović, A., Golijan, J., Babić, V., Kravić, N., Sečanski, M. \& Delić, N. (2016): Organic farming as a factor for biodiversity conservation. In proceedings of International scientific conference on Ecological crisis: Technogenesis and climate change. Beograd, 21-23.april, 2016.

Sala O. E. et al. (2000): Global Biodiversity Scenarios for the Year 2100. Science, 287: $1770-1774$.

Shannon, D., Sen, A. M., Johnson, D. B. (2002): A comparative study of the microbiology of soils managed under organic and conventional regimes. Soil Use and Management, 18(s1): 274-283.

Stolze, M., Piorr, A., Häring, A. M., Dabbert, S. (2000): Environmental impacts of organic farming in Europe, 6: 64-65.

Schneiders, A., Van Daele, T., Van Landuyt, W., \& Van Reeth, W. (2012). Biodiversity and ecosystem services: Complementary approaches for ecosystem management?. Ecological Indicators, 21: 123-133.

Tilman, D., Fargione, J., Wolff, B., D'Antonio, C., Dobson, A., Howarth, R., Swackhamer, D. (2001): Forecasting agriculturally driven global environmental change. Science, 292 (5515): 281-284.

UNEP, 2006. Available at:

http://www.unep.org/pdf/annualreport/UNEP_AR_2006_English.pdf (site accessed: 2.4.2016).

Veličković, M. (1997): Značaj voćarstva za životnu sredinu. Ecologica, 14 (2): 1-4.

Weibull, A. C., Östman, Ö., Granqvist, Å. (2003): Species richness in agroecosystems: the effect of landscape, habitat and farm management. Biodiversity \& Conservation, 12 (7): 1335-1355.

Wickramasinghe, L. P., Harris, S., Jones, G., \& Vaughan, N. (2003): Bat activity and species richness on organic and conventional farms: impact of agricultural intensification. Journal of Applied Ecology, 40(6), 984-993.

http://www.zzps.rs/novo/index.php?jezik=sr\&strana=zastita_prirode bioloska_raznovrsn ost biodiverzitet (site accessed: 28.3.2016.)

www.iucn.org. (site accessed: 1.4.2016.)

https://cmsdata.iucn.org/.../iucn_red list_leaflet_serbia_march11.pdf (site accessed: 1.4.2016.) 


\title{
BIODIVERZITET I ORGANSKA POLJOPRIVREDA
}

\author{
Milovan Veličković ${ }^{1}$, Jelena Golijan ${ }^{1}$ i Aleksandar Popović ${ }^{2}$ \\ ${ }^{1}$ Poljoprivredni fakultet, Univerzitet u Beogradu-Zemun, Srbija \\ ${ }^{2}$ Institut za kukuruz "Zemun Polje", Beograd, Srbija \\ e-mail: mvelicko@agrif.bg.ac.rs
}

\section{Rezime}

Biodiverzitet na planeti Zemlji ugrožen je već decenijama, pre svega posledicama ljudskih aktivnosti. Prema dosadašnjim naučnim saznanjima, broj vrsta se smanjuje brzinom od 1000 do 10000 puta većom u odnosu na ranija vremena. Iako je međunarodni strateški cilj zaustavljanje promena u postojećem biodiverzitetu na globalnom planu, činjenica je da svakodnevno nestane čak 74 vrste, odnosno ukupno 27000 vrsta godišnje, što podrazumeva nestanak $20 \%$ postojećih vrsta $\mathrm{u}$ naredne tri do četiri decenije. Očuvanje biodiverziteta predstavlja jedno od najznačajnijih ciljeva globalne zaštite životne sredine, u čijem ostvarenju učestvuju i nauka i politika. Usvojene Konvencije o biološkoj raznovrsnosti i biodiverzitetu, daju naznaku ključnog napretka ka ostvarenju Strateškog plana za biodiverzitet u periodu od 2011-2020. godine. Biološka raznovrsnost zahteva sveobuhvatnu pomoć savremenog čoveka, na svim nivoima rada, u cilju očuvanja i obogaćivanja postojećeg biodiverziteta. Kako bi se zaštitile brojne i veoma retke vrste, pravni propisi, pre svega Zakon o zaštiti prirode, moraju se uvesti i strogo poštovati. Sistem organske proizvodnje omogućava očuvanje ne samo lokalnog, već i globalnog biodiverziteta. Prema svim dosadašnjim naučnim istraživanjima dokazano je da ovaj sistem poljoprivredne proizvodnje povećava ne samo broj različitih vrsta organizama, već i njihov ukupan rast, sa malim varijacijama između različitih taksonomskih grupa.

Ključne reči: biodiverzitet, ugrožene vrste, životna sredina, Konvencije o biološkoj raznovrsnosti, organska proizvodnja. 